\title{
THE EXISTENCE OF ARABIC LANGUAGE IN INDONESIAN SOURCE TEXT AND ENGLISH TARGET TEXT \\ Erlina Zulkifli Mahmud ${ }^{1 *}$, Bima Bayusena ${ }^{2}$, Ratna Erika Mawarrani ${ }^{3}$ \\ ${ }^{1 *, 2,3}$ Faculty of Cultural Sciences, Universitas Padjadjaran, Indonesia. \\ Email: ${ }^{1 *}$ erlina@unpad.ac.id, ${ }^{2}$ bimabayusena@unpad.ac.id, ${ }^{3}$ ratna.erika@unpad.ac.id
}

Article History: Received on $28^{\text {th }}$ March 2020, Revised on $21^{\text {st }}$ May 2020, Published on $19^{\text {th }}$ June 2020

\begin{abstract}
Purpose: To study the existence of the Arabic language in the Indonesian language mostly limited to terms used in Islam religion.

Methodology: This article discusses the existence of Arabic literature in the Indonesian source text, a novel with the life in a pesantren as the setting, where the author of the source text needs to translate the Arabic expressions used in the story into Indonesian. Then from the Indonesian source text, the novel is translated into English. The method used in this research is the descriptive comparative method. The leading theory used for this research is the strategies of Translation by Vinay and Darbelnet (1995), what Arabic linguistic units involved in the Indonesian source text, and what strategy of conversion used by the author and the translator become the objectives of this research.
\end{abstract}

Principal Findings: The results show that the Arabic linguistic units found are ranging from a word into a clause or sentence, and the strategies of Translation used in the target text do not always deal with one single procedure; sometimes, it involves a combination of some procedures.

Applications of this study: The translation work may lead to similar as well as a contrastive linguistic phenomenon. People can learn more about languages involving in a translation, particularly when the structures of the source and target language are compared linguistically.

Novelty/Originality of this study: This study covers the gap left in the previous research carried out by the same team entitled "Translation Equivalences of Islamic Terms in the Novel (The Land of Five Towers 'Negeri Lima Menara'). This previous research used the same data source, Arabic expressions, in the novel. It focused more on the Arabic feelings relating to Islamic terms, such as names of five obligational prayers, names of optional prayers, activities in shalat, or praying. The rest of the Arabic phrases which are not used in this previous research are left unstudied.

Keywords: Arabic Language, Translation, Strategies of Translation, Source Text, Target Text.

\section{INTRODUCTION}

This research entitled "The Existence of Arabic Language in Indonesian Source Text and English Target Text" deals with the phenomenon found in a novel written in Indonesian language Negeri 5 Menara ('The Land of Five Towers'). This novel reveals a significant number of Arabic expressions indicating not only Islamic rules, Islamic proverbs, but also most parts of other daily activities; praying, studying, including academic activities, school rules, and names of subjects. This use of Arabic language mostly deals with Islam, religion, and religion is a part of the culture, therefore, translating the expressions will deal with the translating culture-specific items, CSIs (Afrouz, 2019; Al-khresheh, Khaerurrozikin, \& Zaid, 2020). The Arabic emotions present in the novel as borrowing accompanied by their equivalents expressed in two forms; footnotes that are put at the bottom of a page where the Arabic expressions appeared and in the way of descriptions that are embedded into the text following the borrowed Arabic phrases. The novel Negeri 5 Menara ('The Land of Five Towers') where the Arabic phrases are located, has been translated into English since October 2011. Since the novel used as the source text for this research is the 25 the publication and the translated novel is the third publication, it strongly suggests that it has been the best seller story starting from the first publication in July 2009. The ways the author of this novel uses the Arabic expressions broaden the knowledge of its readers; the information is given as the equivalent of an Arabic expression in the book uncovers any possible barrier in comprehending the foreign words, in this case, Arabic phrases. As it is a literary work that supposed to entertain its readers and it will not choose who to read it, the author presents the Arabic phrases in transliteration; anybody who is not able to read Arabic letters can follow the content of the story.

The next background of this study is the gap left in the previous research carried out by the same team entitled "Translation Equivalences of Islamic Terms in the Novel (The Land of Five Towers 'Negeri Lima Menara') published in an international journal (Mahmud, Bayusena, \&Mawarrani, 2018). This previous research used the same data source, Arabic expressions, in the novel. It focused more on the Arabic feelings relating to Islamic terms, such as names of five obligational prayers, names of optional prayers, activities in shalat, or praying. And the translation instruments which are applied are the techniques of Translation. While locating those Islamic terms, which are Arabic feelings, almost all of the Arabic expressions that occurred in the novel have also been collected. The rest of the Arabic phrases which are not used in this previous research are left unstudied.

Unlike researches about Translation, which usually deals with two languages, this research covers three words altogether in one single source, a novel written in the Indonesian language yet involves Arabic expressions as borrowing translated 
into the Indonesian language written in the source text as a part of the story. The whole work, which is then translated into English as the target text, opens another gap on how the Arabic expressions are translated, which are so far only shown in their equivalents. All the data in this research allow carrying out more research. What changes found and what kinds of shifts occurred in the data can be some possible objectives to be discussed thoroughly in the next study collaborating with researchers who have Arabic competence. Insyaa Allah.

From the backgrounds described, the objectives of this research are:

1. To identify the linguistic units of Arabic expressions used in the source text;

2. To find out the themes involved in the Arabic phrases;

3. To describe the strategies of Translation applied.

\section{LITERATURE REVIEW}

The translation is the process of conveying a written text from one language to another one (Al-khresheh \& Almaaytah, 2018). Translation Studies as a part of Applied Linguistics can be considered as a new discipline of various interests; the fact that some terminologies used in these Studies found overlapping confirms this situation. Some scholars still argue up till now about some basic terms to be applied; methods of Translation, strategies of reading, or techniques of reading; (Vinay and Darbelnet 1995) use the term strategies to cover the process of reading while (Newmark, 1988) simply uses the term method (Owji, 2013). However, they all agree with the use of the term procedures as the techniques of translating. This is not to be put as a problem as what to use will depend on what one is looking for in research.

Translation Studies deals with languages involved in an activity called Translation, therefore, people can compare what characteristics of a specific style represented in a text called source language text or simply called source text, a text to be translated, as well as in a document called target language text or simply called target text, a text having been translated (Erlina, 2016). As it involves at least two languages, some scholars use these Studies for their research in other linguistic studies, namely Contrastive or Comparative linguistics, as described in a journal article entitled "Technique and Method's of Translation" (Umamaheshwari, 2016). This is possible as in the classic definition, and Translation refers to two languages (source language and target language), and the work of Translation deals with one piece of the message expressed in two different styles (Umamaheshwari, 2016, Suryawinata, Zuchridin, \& Hariyanto, 2016). This shows that translation work may lead to similar as well as a contrastive linguistic phenomenon. People can learn more about languages involving in a translation, particularly when the structures of the source and target language are compared linguistically (Al-khresheh, 2015, 2016A \& 2016B).

\section{Previous Researches}

As this research makes use of a novel as the data source which happens to be the best seller novel, it has opened the opportunity for scholars, researchers, undergraduate students to perform research regarding its content. The previous investigations dealing with the content of this novel among others are those who have made this novel observed and studied for their thesis: Nilai-Nilai Pendidikan Islam Dalam Novel Trilogi Negeri 5 Menara Karya Ahmad Fuadi ('The Values of Islamic Education in the Trilogy Novel The Land of Five Towers Written by Ahmad Fuadi') (Gatpandan\& Ambat, 2017; Suryawinata et al, 2016). She discussed the Islamic norms in the education process in the novel. Almost similar to this research is "Nilai-Nilai Pendidikan Akhlak yang Terkandung Dalam Novel Negeri 5 Menara Karya Ahmad Fuadi ('The Values of Moral Education in the Novel The Land of Five Towers by Ahmad Fuadi'), IAIN Raden Intan, Lampung (Muyasyaroh, 2017). The theme in this research is more general as the previous one focused on the Islamic norms while the second one focused on all norms which regulate good attitudes in society. The third one is also a thesis written in English entitled "A Translation Analysis of Address Terms of Negeri 5 Menara (The Land of Five Towers') in The Land of Five Towers, Faculty of Language and Arts, UNY, Yogyakarta (Safitri, 2015). This research discussed the Translation of pronouns, kinships, titles, and names used in the novel using Molina \& Albir's (Fitriani, 2014) techniques of Translation. Using English as well, the next previous research with the same data source, the novel Negeri 5 Menara ('The Land of Five Towers') and its translation "The Land of Five Towers" was done in 2018 regarding Minangkabau cultural words. The title is "Strategies in Translating Minangkabau (the name of a tribe in West Sumatra, Indonesia) Cultural Words in The Land of Five Towers 'Negeri Lima Menara' ('The Land of Five Towers'), Fuadi's Novel (Muyasyaroh, 2017). The strategies of Translation used there are of Baker's; translation strategies used by professional translators at a word level. The next research which also uses this same novel is done in 2018 (Mahmud, 2018) they talk about translation methods, translation procedures, and the changes regarding the additional information as well as omissions. The latest research regarding this novel which is used as a reference is entitled "Translation Equivalences of Islamic Terms in the Novel (The Land of Five Towers 'Negeri Lima Menara'). Using the model of translation techniques given by Molina \& Albir (Hermawan, Tanjung, 2018), this research focused on Arabic expressions of Islamic terms only (Muyasyaroh, 2017). They are all the references dealing with the novel Negeri Lima Menara and its Translation used in this present research.

This present research does not talk about the content of the novel as a whole nor about the moral values; this research talks about the existence of Arabic language in the Indonesian source text, the phenomenon in translating those Arabic expressions into Indonesian as the source text and the phenomenon revealed in translating the Arabic expressions 
through their equivalents in Indonesian language text into English. It deals with three languages; Indonesian language, Arabic language, and English. Commonly translation work deals with two languages but the fact is that some literary works involve more than two languages altogether. The use of three languages in one literary work like books and novels does exist and research about the involvement of three languages has already been done. In 2018 a research entitled "Documenting Sundanese Literature by The Presentation of Its Folklores Written in Three Languages" was published (Molina \& Hurtado, 2002). It discusses how the three languages presented in one single work, a book. The target texts Indonesian language text and English language text put individually in the book. The research discusses how Sundanese (the local language of West Java culture) text is translated into Indonesian as well as into English. It compares the methods of Translation used in the two target texts. It is different from the present research where the target text is one but the source text involves two languages altogether with the Indonesian language itself as the source language accompanied by Arabic as a foreign language functioned as borrowing.

The tools used to study the data in this research are strategies of Translation by Vinay and Darbelnet (1995). Their model has been used in recent researches. Some of them deal with the Translation from Persian into English and vice versa, such as in the comparative study of strategies used in translating "The Old Man and the Sea" from English into Persian done in 2017. What becomes the objective of this research is the frequency of strategy used between direct Translation and oblique Translation (Mahmud, Ampera, \& Sidiq, 2018). The next research is about exploring strategies of Translation in translating economic terms from English into Persian. In this research done in 2015, some strategies of different scholars are applied including those strategies of Translation by Vinay and Darbelnet (1995), and Heshmatifar and Biria (2015). Still, about the Translation from Persian into English, this Vinay and Darbelnet's model is seen to be used also in research about translating Forough Farrokhzad's selected poems by a native and a non-native speaker. In this research three new procedures called complementary procedures added, consisting of amplification, economy, and explicitation (Heshmatifar \& Biria, 2015). Those three new procedures are also used in this present research dealing with the existence of the Arabic language in the Indonesian source text. The difference between what Shabani, et.al have done with this present research is that this present research does not make the comparison of translation work of more than one translator; it is about a translated work by one single translator.

Dealing with Vinay and Darbelnet's model of strategies in Translation, a research article by an Indonesian scholar, Sutarno, Sinar, Lubis, and Ibrahim-Bell (2000) was published. It discusses which strategy of Translation dominant in translating religious text called Maitreya Buddhist text. The translation work discussed there is the Translation from Mandarin into Indonesian. The result of the research is to be shared with more translators who work with religious Buddhist texts so they will have a kind of guideline on how to translate other religious texts (Shabani, Emadi, \& Daftari, 2019). Unlike this current research, this research article deals with a novel, a literary work, not a religious text. Using the same strategies by Vinay and Darbelnet, some Iranian scholars applied them to the Translation of slogans in clothing brand advertising (Sutarno, et al., 2000). They come up with the result that the most frequently used strategy is literal Translation under the direct translation strategy.

The next thing studied to be used as references in this research is on the Translation of Arabic either from Indonesian or into Indonesian. It is about the existence of the Arabic language. How Arabic in various texts is translated put under some researches, for example, the one by Perdana (the name of a person in Indonesia). According to him, it is important to be aware of which strategy of Translation used in translating the Arabic language so that the translation work can be accepted and easily comprehended. The background that Indonesian learned Arabic through the understanding of Islam borrowed words for the use in the academic field especially in pesantren 'Islamic boarding school' becomes the topic discussed there (Reza\& Qadimi, 2016). More research in the Translation of Arabic language used as references focused on the strategy used to translate Indonesian language academic texts into Arabic in structural aspect, semantic aspect, and the appropriateness in the terminological aspect is done in 2016 (Perdana, 2017). The characteristics of the Arabic language identified in these researches are of any help to translators as well as to scholars especially those who are researching the Arabic language.

As it can be located in the novel that the linguistic units used to present the Arabic expressions ranging from words to sentences, the theoretical framework used to study this phenomenon is the strategies of Translation by Vinay and Darbelnet (1995). The strategies of Translation by Vinay and Darbelnet can accommodate most of the data found in the novel becomes the only reason this model is used.

\section{Theoretical Framework: Strategies of Translation by Vinay and Darbelnet (1995)}

This research uses strategies of Translation proposed by Vinay and Darbelnet (1995) in their book "Comparative Stylistics of French and English: A Methodology for translation" Vinay and Darbelnet (1995). There are two strategies under the terms of direct Translation and oblique Translation. Each of the strategies has its procedures functioning as the technical tools which can be applied to the data. The first strategy, direct Translation, deals with procedures that can cover the work of Translation directly putting aside all other assumptions regarding the process of Translation. The three of them are (1) Borrowing: it transfers the words or expressions from one language into another language, for example: shalat (Arabic) 'prayer' - shalat (Indonesian) 'prayer'. (2) Calque: almost similar to borrowing but dealing with phrases linguistic units, for example, Tsaqafah Islamiyah (Arabic) 'Islam Civilization' - Peradaban (Civilization) Islam 
(Indonesian). (3) Literal Translation: it translates word by word, keeping the structure of the source language text, for example: "Syukran ya take!" (Arabic) 'Thank you, brother' - Thank you brother (English).

The second strategies, oblique Translation covers four procedures (1) transposition: it changes the part of speech without altering the meaning, for example, the verb in hug me ('Beri says Pelikan' the Translation of "Give me a hug") in English is translated into Indonesian 'Peluk saya' ('Hug me') where the noun hug shifted into a verb 'peluk' ('hug'). (2) modulation: it involves the changes in the viewpoint. This has subdivisions; Abstract for Concrete (and vice versa), for example: "I live in the wild" - "Saya hidup di hutan" ('I live in the forest') the wild which is abstract is translated into 'human' ('forest') concrete thing referring to the forest; The Part for the Whole (and Vice Versa), One Part for Another, Cause for the Effect, Reversal of terms, Negation of opposite, Active to Passive (and Vice Versa), Space for time (and Vice Versa), change of symbols, and Exchange of Intervals for Limit. (3) Equivalence: dealing with the Translation of idioms and proverbs, for example, the Indonesian proverb "Berakit-rakit ke Hulu berenang-renang ke tepian, bersakitSakit dahulu bersenang-senang kemudian" ('Paddling a raft to the upstream, swimming to the bank, having pain first, having fun later') is translated into English 'No gain without pain'. (4) adaptation: it refers to a total change where what is kept is only the message, for example, "Dear Sir" at the beginning of a letter is translated into 'Dengan Hormat' ('with respect') in the Indonesian language.

As the data of the Arabic expressions cannot be facilitated with those seven procedures, there are supplement procedures added to this research; (1) amplification; the procedure of adding information to the equivalent, for example, Ramadhan (Arabic) - Bulan Ramadhan (Indonesian) - Ramadhan month (English). (2) economy: as opposed to amplification, so this procedure deals with the process of omitting information, for example, Arabic translators usually omit taboo words ('shit') from their translations. (3) explicitation; it deals with implicit information which is translated into explicit, for example, the acronym in Indonesian ABRI is translated into ABRI (Angkatan Bersenjata Republik Indonesia) 'army'.

\section{MATERIALS AND METHODS}

All data in this research are taken from a literary work; a novel, entitled Negeri 5 Menara ('The Land of Five Towers') by A. Fuadi and its translation "The Land of Five Towers" translated by Angie Kilbane (Alawiyah et al., 2016). This novel has been one of the best seller novels in Indonesia since it was published the first time in July 2009. The one that is used as the data source of the source language text for this research is the $25^{\text {th }}$ edition, published in September 2016. While the one that is used as the data source of the target language text "The Land of Five Towers" is the 3 rd edition, published in May 2016 (Fuadi, 2016a). There are more than 70 data of Arabic expressions found in the novel but only $80 \%$ of it used for this research. The $20 \%$ which are not used because they are the same words or expressions occurred several times repeatedly and some other data collected have been used in the previous research (in 2018). It is, therefore, the collection of data for this present research is fresh data.

\section{Research Design}

Like other most social scientific researches, the method used is a descriptive qualitative one. First of all, all Arabic expressions including, words, phrases, clauses and sentences appeared in the source language text are collected. The Arabic expressions used in the novel are not written in Arabic letters; they have been transliterated, therefore what will be discussed in the analysis are not in the form of Arabic letters.

After all the Arabic expressions are collected, the next step is to compare the source language data with their translations in the target language text (English). All then are listed in a table consisting each Arabic expression with or without its equivalent as the information described by the author in the Indonesian language; some Arabic expressions do not have their equivalents in the source Indonesian text for they deal with Islamic terms which are considered to be common for the readership of the source text. The table is also provided by the page number where the Arabic expression was found in the source language text, the equivalent in the target language (English), and also the page number of the equivalent in the target language text. For the simplicity of the writing of this research, this present research omits the page number in each data in the master table.

After all, data have been located in the table, they were categorized based on the strategies of Translation, Vinay, and Darbelnet's model (1995). The next step is to make new tables based on the strategies of Translation. Coming to the final step is to analyze the data based on the characteristics of each strategy and procedure. All then are described in the article to be sent. From the process of collecting data up to the writing of the research result, it takes almost six months.

\section{RESULTS AND DISCUSSION}

The results of this research show that from the two strategies (direct Translation and oblique Translation), not all procedures are used in translating Arabic expressions from the Indonesian source text into the English target text. There are only two procedures in the direct translation strategy involved; borrowing and literal Translation. Calque which deals mostly with phrases is not found in the data as the phrase structure of Indonesian and English is not the same, especially noun phrases. From the first strategy, it can be identified the use of (1) literal translation and (2) the combination of two procedures namely borrowing and literal Translation. While in the second strategy, oblique translation strategy, all procedures (transposition, modulation, equivalence, and adaptation) can be located. In the modulation procedures, there only four types found; Abstract for Concrete (and Vice Versa), The Part for the Whole (and Vice Versa), One Part for 
Another, and Active to Passive (and Vice Versa). The rest of the data are identified using additional translational procedures namely; amplification, economy, and explicitation.

The equivalents given both by the author and the translator regarding the existence of the Arabic language give a positive impact to the readers of the source language text and the readers of the target language text that they receive semantic information as well as pragmatic meaning dealing with Arabic expressions used. Knowing any information about those Arabic expressions is one of the initial and effective ways to learn this language linguistically and culturally.

\section{Direct Translation Strategy}

Table 1a shows that the linguistic units of Arabic expressions that occurred in the Indonesian source text are sentences (as in data 1 and 2), word (in data 3), and phrases (in data 4 and 5). The Arabic expression Allahummaftah Alaina hikmatan wansur Alaina birahmatika ya arrhamarrahimin (Our Lord, please open us to wisdom and help us with Your Mercy, oh Most Gracious) in (1) is a prayer. The equivalent of it is given directly in the text after the Arabic expression while in the English target text, the Arabic expression is not used. The translator decides to use the direct translation strategies; literal Translation without borrowing.

Table 1a: Direct Translation Strategy; Literal Translation

\begin{tabular}{|c|c|c|c|}
\hline No. & Arabic Language & Indonesian Source Text & English Target Text \\
\hline 1 & $\begin{array}{l}\text { Allahummaftah alaina hikmatan } \\
\text { wansur alaina birahmatika ya } \\
\text { arrhamarrahimin. } \\
\text { (Our Lord, please open us to } \\
\text { wisdom and help us with Your } \\
\text { Mercy, oh Most Gracious) }\end{array}$ & $\begin{array}{l}\text { "Allahummaftah alaina hikmatan } \\
\text { wansur alaina birahmatika ya } \\
\text { arrhamarrahimin." Tuhan Kami, } \\
\text { bukakanlah kepada kami hikmah, } \\
\text { dan bantulah kami dengan } \\
\text { rahmatMu, wahai Sang Maha } \\
\text { Pengasih. } \\
\text { (Our Lord, please open us to } \\
\text { wisdom and help us with Your } \\
\text { Mercy, oh Most Gracious) }\end{array}$ & $\begin{array}{l}\text { Our Lord, open us to } \\
\text { wisdom and help us with } \\
\text { Your mercy, oh Most } \\
\text { Gracious" }\end{array}$ \\
\hline 2 & $\begin{array}{l}\text { Qif ya akhi } \\
\text { (Stop, brother) }\end{array}$ & 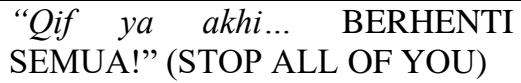 & "STOP ALL OF YOU!" \\
\hline 3 & $\begin{array}{l}\text { Majnun } \\
\text { (Crazy) }\end{array}$ & $\begin{array}{l}\text { "Majnun43 anta, ini seperti } \\
\text { pungguk merindukan bulan," } \\
\text { sambutku. (You are crazy, this is } \\
\text { like a wolf longing for the moon) } \\
43 \text { Gila (Crazy) }\end{array}$ & $\begin{array}{l}\text { "You're nuts, this is like a } \\
\text { wolf longing for the } \\
\text { moon," I said. }\end{array}$ \\
\hline 4 & $\begin{array}{l}\text { Sunnatullah } \\
\text { (This is God's law) }\end{array}$ & $\begin{array}{l}\text { Ini sunnatullah-hukum Tuhan. } \\
\text { (This is God's law) }\end{array}$ & This is God's law. \\
\hline 5 & $\begin{array}{l}\text { Durusul Lughoh } \\
\text { (Arabic Studies) }\end{array}$ & $\begin{array}{l}\text {...karena sedang asyik dengan buku } \\
\text { Durusul Lughoh31 nya. } \\
31 \text { Pelajaran Bahasa Arab } \\
\text { (Arabic Studies) }\end{array}$ & $\begin{array}{l}\text {...because he was } \\
\text { absorbed in his Arabic } \\
\text { Studies book. }\end{array}$ \\
\hline
\end{tabular}

The same thing occurred in data (2), there is no borrowing just literal Translation from the equivalent given in the source text "BERHENTI SEMUA!" (STOP ALL OF YOU) of daily conversation. In data (3 and 5), the equivalents of the Arabic expressions majnun (crazy) which has a theme as a part of daily conversation and durusul lughoh (Arabic Studies) as the name of a subject given in the class are given as footnotes while in the English target text, the translator uses the content of the notes embedded into the text directly as the literal Translation, a part of direct translation strategies.

With the equivalents accompanied the Arabic expressions either as footnotes or description following the borrowing, the readership of the Indonesian source text will get the benefit from this, they will get the information about the content in the Arabic expressions. The same thing will also happen with the readership of the English target text, but as there are no Arabic expressions there, they will not be able to feel the same environment of the setting of the novel which is an Islamic boarding school where Arabic and English are daily used by the students there.

Table 1b: Direct Translation Strategy; Borrowing + Literal Translation

\begin{tabular}{lllll}
\hline No. & Arabic Language & & Indonesian Language Text & English Language Text \\
\hline 1 & $\begin{array}{l}\text { Quill Haqqani walau kaana } \\
\text { murran } \\
\begin{array}{l}\text { Say the truth even when it's } \\
\text { bitter) }\end{array}\end{array}$ & $\begin{array}{l}\text { Katakanlah kebenaran walau itu } \\
\text { pahit } \\
\text { (Say the truth even when it's bitter) }\end{array}$ & $\begin{array}{l}\text { kaana murran. Say the } \\
\text { truth even when it's bitter }\end{array}$ \\
\hline 2 & Uthlub ilma minal Mahdi ila lahdi & Uthlub ilma minal Mahdi ila lahdi. & Uthlub ilma minal Mahdi \\
\hline
\end{tabular}


(Seek knowledge from the cradle Tuntutlah ilmu dari buaian sampai to the grave)

\begin{tabular}{ll}
\hline 3 & $\begin{array}{l}\text { Innallaha jamiil wahuwa yuhibbul } \\
\text { jamal. } \\
\text { (Verily Go is beautiful and loves } \\
\text { beauty) }\end{array}$ \\
\hline $4 \quad$ & $\begin{array}{l}\text { Allahumma zidna ilman war } \\
\text { zuqna fahman... } \\
\text { (Lord, please add our knowledge } \\
\text { and grant us understanding) }\end{array}$
\end{tabular}

\begin{tabular}{ll}
\hline 5 & $\begin{array}{l}\text { Afwan ya Uztad, nasiitu } \\
\text { (I am sorry, teacher. I forgot) }\end{array}$ \\
\hline 6 & $\begin{array}{l}\text { Sa'ah saadisah tamaman. } \\
\text { (Six o'clock sharp) }\end{array}$ \\
\hline 7 & $\begin{array}{l}\text { Fahimta. } \\
\text { (Do you understand?) }\end{array}$ \\
\hline 8 & $\begin{array}{l}\text { i'malu fauqa ma'amilu } \\
\text { (To do more than what have been } \\
\text { done by others) }\end{array}$ \\
\end{tabular}

\begin{tabular}{ll}
\hline 9 & $\begin{array}{l}\text { Innallah Maa'na } \\
\text { (Allah is with us) }\end{array}$ \\
\hline 10 & $\begin{array}{l}\text { Muhadharah } \\
\text { (Public speaking training) }\end{array}$
\end{tabular}

rahmatan lil Alamin
(bringing blessing for the world
and the hereafter)

$12 \quad \begin{aligned} & \text { khutbatul wada } \\ & \text { (A farewell sermon) }\end{aligned}$

\begin{tabular}{|c|c|c|c|}
\hline 13 & $\begin{array}{l}\text { Kismul Amni } \\
\text { (Security) }\end{array}$ & $\begin{array}{l}\text { "Kismul Amni" --- } \\
\text { Keamanan. } \\
\text { (Security) }\end{array}$ & Kismul Amni-Security. \\
\hline 14 & $\begin{array}{l}\text { Jasus } \\
\text { (Spies) }\end{array}$ & $\begin{array}{l}\text {...sebagai jasus. Mata-mata," } \\
\text { (Spies) }\end{array}$ & ...as jasus. Spies," \\
\hline 15 & $\begin{array}{l}\text { Al Barq } \\
\text { (The Lightning) }\end{array}$ & $\begin{array}{l}\text { Al Barq, yang berarti petir. } \\
\text { (The Lightning) }\end{array}$ & $\begin{array}{l}\text { Al-Barq, which means } \\
\text { 'lightning'. }\end{array}$ \\
\hline 16 & $\begin{array}{l}\text { Maktabah } \\
\text { (Library) }\end{array}$ & $\begin{array}{l}\text { maktabah atau library, } \\
\text { (Library) }\end{array}$ & the maktabah or library. \\
\hline 17 & $\begin{array}{l}\text { Abu naum } \\
\text { (those who love sleeping) }\end{array}$ & $\begin{array}{l}\text { Abu naum atau orang yang suka } \\
\text { tidur. } \\
\text { (those who love sleeping) }\end{array}$ & $\begin{array}{l}\text { Abu naum, or people who } \\
\text { love to sleep }\end{array}$ \\
\hline 18 & $\begin{array}{l}\text { akhlakul karimah } \\
\text { (good character) }\end{array}$ & $\begin{array}{l}\text { Apakah ini akhlakul karimah27 } \\
\text { yang diajarkan agama? } \\
27 \text { Akhlak yang baik } \\
\text { (good character) }\end{array}$ & $\begin{array}{l}\text { Was this akhlakul } \\
\text { karimah, good character, } \\
\text { taught by religion? }\end{array}$ \\
\hline 19 & $\begin{array}{l}\text { "Haaza kitaabun." } \\
\text { (This is a book) }\end{array}$ & $\begin{array}{l}\text { "Haaza kitaabun32." } \\
32 \text { Ini buku (Arab) } \\
\text { (This is a book) in Arabic }\end{array}$ & $\begin{array}{l}\text { "Haaza kitaabun7" } \\
7 \text { This is a book (Arabic) }\end{array}$ \\
\hline 20 & Ana khair & Ana khair 69. & Ana khair, I'm fine, ... \\
\hline
\end{tabular}

ila lahdi. Seek knowledge from the cradle to the grave.

(Seek knowledge from the cradle to the grave)

Innallaha jamiil wahuwa yuhibbul jamal. Sesungguhnya Tuhan itu indah dan mencintai keindahan.

(Verily Go is beautiful and loves beauty)

Allahumma zidna ilman war zuqna fahman... Tuhan tambahkan ilmu kami dan anugerahkanlah pemahaman...

(Lord, please add our knowledge and grant us understanding)

"Afwan ya Uztad, nasiitu. Maaf "Afwan ya Uztad, nasiitu. saya Lupa. (I am sorry, teacher. I forgot)

Sa'ah saadisah tamaman." Jam Sa'ah saadisah enam tepat. tamaman."Six o'clock (Six o'clock sharp) sharp. Fahimta. Ngerti, kan?" (Do you understand?) ...i'malu fauqa ma'amilu. Berbuat I'malu fauqa ma'amilu. lebih dari apa yang diperbuat orang Doing more than what is lain. done by others.

(To do more than what have been done by others)

Innallah Maa'na. Tuhan bersama Innallah Maa'na. God is
kita. with us.

(God is with us) muhadharah, atau latihan berpidato muhadharah, or public di depan umum. (Public speaking training) rahmatan lil alamin, membawa rahmatan lil alamin, keberkahan Dunia dan akherat," bringing blessing for the (bringing blessing for the world and world and the hereafter the hereafter)

khutbatul wada, Khutbah khutbatul wada'. A
perpisahan. farewell sermon.

Innallaha jamiil wahuwa Verily God is beautiful and loves Allahumma zidna ilman add to our knowledge and grant us understanding.

"Afwan ya Uztad,

speaking training. Keamanan. ...sebagai jasus. Mata-mata," $\quad$...as jasus. Spies,' (The Lightning) atau library 'lightning'. (Library) tidur. love to sleep (those who love sleeping) yang diajarkan agama? (C) Mahmud et al.
"Kismul Amni” --- Bagian Kismul Amni-Security. 


\begin{tabular}{llll}
\hline & (I am fine) & 69 Saya baik-baik saja & \\
(I am fine) & & \\
\hline 21 & Tajammu & tajammu 70 sambil ngopi... & tajammu29, \\
& (Hang out while dining) & 70 Bahasa slang Arab ala PM drinking coffee. \\
& berkumpul bersama sambil makan 29 Arabic slang ala MP; \\
& (It's an Arabic slang ala MP to gather together and eat \\
& refer to hanging out while dining) & \\
\hline
\end{tabular}

The combination of two procedures, borrowing and literal Translation, within the same translation strategy, the direct Translation which is shown in table $1 . b$ involves the highest quantity of data ranging from sentences or clauses (1-9 \& $19-20)$, phrases $(11-13,17-18)$, to words $(14-16$, \& 21). Data $(1-17)$ show that the equivalents of the Arabic expressions are located directly after the borrowing words; everything mentioned in the target text is the same as what is stated in the source text. In data (18) the equivalent of the Arabic expression akhlakul karimah ('good character') in the Indonesian source text is located as footnotes but in the English target text, the equivalent is added directly within the sentence not as footnotes anymore. Unlike the case in data (18), the Arabic expressions in data (19 - 21) are translated differently; the equivalents given as footnotes in the Indonesian source text are similarly kept in the target text; the equivalents are also given as footnotes.

From the data shown in this table, it is assumed that the translator chooses this combination of procedures under direct translation strategy the same as used in the source text because the text deals with prayers, the communication with God; nobody would like to risk creating something different to minimize the possible mistakes and misunderstanding. Some others deal with proverbs or wise words where structural and semantic shifts are not allowed as they are cultural. The rest of the data deal with simple daily conversation which does not need any complicated form of equivalent. In this way, the readership of the target text and the source text will get the same message, the same understanding. This kind of combination of procedures under the direct translation strategy is possible to be applied only when the author uses the same combination in the source text where expressions of a foreign language are involved (Sharei, 2017).

\section{Oblique Translation Strategy}

All data in 4.2 deal with the second translation strategy namely oblique translation strategy whose function to be applied to the data which cannot be translated using direct translation strategy.

Table 2a: Oblique Translation Strategy; Transposition + Economy

\begin{tabular}{llll}
\hline No. & Arabic Language & Indonesian Language Text & English Language Text \\
\hline 1 & Ana & "Dengarkan instruksi ana25 baik- "Listen to my instructions \\
& baik." & & \\
& & & \\
& & satunya buat saya dalam bahasa Arab \\
& (I in Arabic is the only pronoun for the \\
& first person singular in the Arabic \\
& language)
\end{tabular}

There is only one case found under this combination of procedures; economy and transposition. What can be seen in this table $2 \mathrm{a}$ is the data involving the change of part of speech; from one linguistic unit called a word classified as a noun "ana"(I) which means 'me' functioning as an object into a possessive pronoun 'my'; transposition is taking place in the Translation. It is not only that what had happened in the data in the English target text, but the equivalent is also given in the source text as footnotes are omitted in the target text so this is the case of economy procedure under the oblique translation strategy.

The missing of the Arabic expression with its equivalent as footnotes will make the readership of the target language text miss the feel of the environment of Islamic boarding school setting where the Arabic language is used daily as much as the English language even it has to be code switched sometimes.

Table 2b.1: Oblique Translation Strategy; Modulation from Abstract for Concrete (and vice versa)

\begin{tabular}{|c|c|c|c|}
\hline No. & Arabic Language & Indonesian Language Text & English Language Text \\
\hline 1 & $\begin{array}{l}\text { saajtahidu fauqa mustawa } \\
\text { al akhar }\end{array}$ & $\begin{array}{l}\text {...saajtahidu fauqa mustawa al akhar. } \\
\text { Bahwa aku akan berjuang dengan } \\
\text { usaha di atas rata-rata yang dilakukan } \\
\text { orang lain. }\end{array}$ & $\begin{array}{l}\text {...saajtahidu fauqa mustawa } \\
\text { al akhar. Fight harder than } \\
\text { the rest. }\end{array}$ \\
\hline 2 & Jami & $\begin{array}{l}\text { Pertama adalah mesjid Jami } 16 \\
16 \text { Jami biasanya digunakan untuk } \\
\text { menamakan mesjid besar. }\end{array}$ & The first is the main mosque \\
\hline
\end{tabular}




\begin{tabular}{lll}
\hline 3 & jiharkah, shaba & $\begin{array}{l}\text { Berturut-turut dia bacakan qalam ilahi He read in various styles. } \\
\text { dengan gaya jiharkah, shaba, dan } \\
\text { banyak lagi. }\end{array}$ \\
\hline $4 \quad$ Rezeki & $\begin{array}{l}\text { Tuhan itu bisa mendatangkan rezeki God can bring blessings to } \\
\text { (the blessing from Allah) } \\
\text { kepada manusia dari jalan yang tidak the man in unexpected ways. } \\
\text { pernah kita sangka-sangka. } \\
\text { (God can bring blessings to human in } \\
\text { the ways that we have never expected } \\
\text { before) }\end{array}$ \\
\hline
\end{tabular}

Table 2b.1 data (1) shows that oblique translation strategy specifically the procedure of modulation Abstract for Concrete (and Vice Versa) is not the only procedure used; borrowing procedure is also used together. Data (1) in this table shows a uniqueness as it can belong to several or multi procedures; from modulation Abstract for Concrete (and Vice Versa), then One Part for Another, to Transposition.

- Abstract for Concrete (and Vice Versa) procedure can be located from the information given in the equivalent BahwaAku akan berjuang dengan Usaha di atas rata-rata yang dilakukan orang was lain (That I will fight more than anybody else ever does) from the Arabic clause saajtahidu fauqa mustawa al akhar (That I will fight more than anybody else ever does) is concrete as it mentions the subject ( $a k u$ 'I') added by what to do and how to do. In the target text, the equivalent changes to abstract; without subject, without how to do. With the existence of the Arabic expression there, the readership of the target language text will get the idea that the message inthe Arabic expression is a motivation to struggle more than others so we will be better than others as mentioned in the sentence 'Fight harder than the rest'.

- One Part for Another procedure can also be located in this first data where the subject "aku" (I) referring to the first person singular as 'I' in English is converted into "you" the second person can be singular as well as plural. In this case, the subject first person singular as one part is translated into an implicit second person singular or plural in an imperative sentence as another.

- The third procedure involved in data (1) is transposition where the reported speech characterized by the word "bahwa" ("that') in the Indonesian source text is converted into a direct sentence; an imperative. The changing of point of view also occurs here and so far it can be categorized as transposition; it deals with the changing type of a sentence.

Still in the same table, in data (2) modulation occurred is from Concrete to Abstract (and Vice Versa); the concrete part is in the source text where the equivalent of the Arabic word "Jami" ('big') in Jami biasanya digunakan Untuk menamakan masjid Besar (Jami which means big is used to refer to a big mosque) is described indicating a building (concrete thing) called a mosque "masjid" (mosque) as well as its size, Besar ('big'). In the target text, the equivalent of it represented by the abstract word "main", a concept referring to its function without any concrete details. It strengthens that the procedure applied in data (2) is modulation with the subdivision Abstract for Concrete. Additionally herein (2) there is no borrowing involved and the footnotes in the source text are omitted in the target text so it is a case of the economy procedure. The last data, data (3) mentioned in this table shows this modulation type of procedure also where the concrete part is in the source text with details style of reciting Al-Quran, jiharkah dan Shaba (the names of styles in reciting Al-Quran). In the target text, those details have been changed into an abstract expression "various" not indicating to what variety involved. As what happens in data (2) the readership of the target text will miss some information, in this case, the name of styles on how to recite Al-Quran.

The next part of this table in data (4) the Arabic expression in the form of a word rezeki (blessing) is not followed by its equivalent. There is no equivalent in the Indonesian source text. The Arabic word which has been borrowed into the Indonesian language is a common term for Indonesian readership, therefore, it can be assumed that the equivalent is not needed there. Seeing from its meaning, the word rezeki (blessing) covers the abstract as well as the concrete things given by Allah in Islam religion while the equivalent in the target text 'blessings' which is abstract covers the abstract thing. The readers of the target text may not know the detail but the procedure chosen here under the oblique translation strategy is represent table to show the same message as obtained by the readers in the source text.

Table 2b.2: Oblique Translation strategy; Modulation from the Part for the Whole (and vice versa)

\begin{tabular}{|c|c|c|c|}
\hline No. & Arabic Language & Indonesian Language Text & English Language Text \\
\hline 1 & man jadda wajada & $\begin{array}{l}\text {...man jadda wajada. Mantera ajaib } \\
\text { berbahasa Arab ini bermakna tegas: } \\
\text { "Siapa yang bersungguh-sungguh, akan } \\
\text { berhasil!" }\end{array}$ & $\begin{array}{l}\text {...man jadda wajada! This } \\
\text { magical Arabic chant had a } \\
\text { short but powerful meaning: } \\
\text { "He who gives his all will } \\
\text { surely succeed". }\end{array}$ \\
\hline 2 & Man shabara zhafira & $\begin{array}{l}\text { "Man shabara zhafira. Siapa yang } \\
\text { bersabar akan beruntung. }\end{array}$ & $\begin{array}{l}\text { "Man shabara zhafira. He who } \\
\text { is patient will fortunate. }\end{array}$ \\
\hline
\end{tabular}




\begin{tabular}{|c|c|c|c|}
\hline 3 & $\begin{array}{l}\text { Man thalabal 'ula sahinal } \\
\text { layali }\end{array}$ & $\begin{array}{l}\text { Man thalabal 'ula sahinal layali. Siapa } \\
\text { yang ingin mendapatkan kemuliaan, } \\
\text { maka bekerjalah sampai jauh malam. }\end{array}$ & $\begin{array}{l}\text { Man thalabal 'ula sahinal } \\
\text { layali. He who wants glory will } \\
\text { work late into the night. }\end{array}$ \\
\hline 4 & Ballighul anni walau aayah & $\begin{array}{l}\text { Ballighul anni walau aayah. Sampaikan } \\
\text { sesuatu dariku, walau hanya sepotong } \\
\text { ayat. }\end{array}$ & $\begin{array}{l}\text {, Ballighul Anni walau aayah. } \\
\text { Deliver something from me, } \\
\text { even if only a part of a verse. }\end{array}$ \\
\hline 5 & $\begin{array}{l}\text { tafadhal ya bunayya } \\
\text { (Please, take this food, my } \\
\text { child) }\end{array}$ & $\begin{array}{l}\text { bukannya bilang "monggo" Tapi akan } \\
\text { bilang "tafadhal ya bunayya39" } \\
\text { (not saying "please" in Javanese } \\
\text { language but instead "please have this } \\
\text { food, my child" in the Arabic } \\
\text { language), } \\
39 \text { Ayo, silakan ambil, anakku (Arab) } \\
39 \text { Please, take this food, my child } \\
\text { (Arabic) }\end{array}$ & $\begin{array}{l}\text { they didn't speak to us in } \\
\text { Javanese but in Arabic... }\end{array}$ \\
\hline
\end{tabular}

Table 2b.2 shows a subdivision of modulation namely The Part for the Whole (and Vice Versa) where the information given in the equivalents of the source text is presented differently in the target text; the part of something in the source text becomes the whole of something in the target text or vice versa. The equivalent for proverbs and wise words in (1) to (3) which are given for all humans not specific for a certain gender (female or male) represented in the Indonesian word 'Siapa' ('who') referring to anybody so it means the whole while the equivalent in the target text syntactically refers to a certain gender of humans namely 'he' (male). By applying the equivalent for the expression "siapa" ('who') with 'he' this indicates the changing of point of view from the whole in the source text to the part in the target text so this is a case of modulation under the oblique translation strategy. In a different case like in data (4) "Ballighul Anni walau aayah" (Share to others even only one single verse), the word "aayah" ('verse') in the Arabic sentence is translated into 'sepotong ayat' ('one single verse') which supposes to have a message one single verse as a whole verse but in the English target text it is translated into 'a part of a verse' with the understanding it is not one verse, only the part not the whole.

The four data from (1) to (4) do not use one single procedure; it is a combination of two procedures, borrowing under the direct translation strategy and modulation of subdivision The Part for the Whole under the oblique translation strategy. The four Arabic expressions are transferred directly into the English target text before they are translated using this subdivision of modulation. As in data (5), the borrowing does not occur; the Arabic expression tafadhal ya bunayya (please take this food, my child) regarding the polite expression to welcome others to take the food provided is translated directly by using modulation The Part for the Whole procedure. The Arabic expression which is in the form of the sentence is translated into the word 'Arabic' in the English target text representing the whole parts of this language. By applying this single procedure modulation with subdivision The Part for the Whole, the translator eliminates the chance for the readers of the target language to get close with the part of the Islamic boarding school environment; using Arabic daily in all activities including in the school cafeteria where the conversation is taking place.

Table 2b.3: Oblique Translation Strategy; Modulation From one Part For Another

\begin{tabular}{llll}
\hline No. & Arabic Language & Indonesian Language Text & English Language Text \\
\hline 1 & qalam ilahi, & qalam ilahi dan sabda Nabi. & $\begin{array}{l}\text { the holy book of Allah and the } \\
\text { sayings of the Prophet }\end{array}$ \\
\hline 2 & $\begin{array}{l}\text { Faslun awwal } \\
\text { ('First grade') }\end{array}$ & $\begin{array}{l}\text { Faslun awwal? Kelas satu kan? } \\
\text { (First grade, right?) }\end{array}$ & Faslun awwal? Year 1, right? \\
\hline
\end{tabular}

Table 2b.3 shows two cases of modulation, the changing of point of view from one part for another. The Arabic expression in (1) is a phrase qalam ilahi ('the words from Allah') which has no equivalent added in the Indonesian source text. It is assumed that the author may think that this term has been one of the Arabic expressions common to the readership of the Indonesian source text so there is no need to explain it in the Indonesian language. When the phrase qalam ilahi ('the words from Allah')containing the meaning "all words from Allah in Al-Quran" is translated into 'the holy book of Allah', it changes the point of view from one part, words from Allah, into the book where the words from Allah are kept. The same thing happens to the second data when the Arabic interrogative sentence "Faslun awwal" ('First grade') is added by its equivalent in Indonesian source text with 'Kelas Satu, kan?' ('First grade, right?'). The word awwal 'beginning' is used to refer to the level of education in schools called kelas ('class') while in the target text, the level of education is not called class but year. If kelas satu ('first grade') is translated literally into class 1, the readership of the target language text will get confused as this term is not common in the English language to refer to a level of education in school or they may also get different understanding. With the equivalent 'year 1' the readership of the target text will get the same message as in the source text so modulation One Part for Another under the oblique translation strategy is applied here. 
Table 2b.4: Oblique Translation Strategy; Modulation From Active to Passive (And Vice Versa)

\begin{tabular}{llll}
\hline No. & Arabic Language & Indonesian Language Text & English Language Text \\
\hline 1 & Kullukum ra'in wa kullukum & Kullukum ra'in wa kullukum "Kullukum ra'in wa \\
masullun an raiyathi & masullun an raiyathi63 & kullukum masullun an \\
& ('Each person is a leader and each & 63 Setiap orang itu pemimpin, dan & raiyathi20." \\
person is responsible to what is led & setiap orang bertanggung jawab atas & 20 Each person is a leader, \\
by her or him') & $\begin{array}{l}\text { apa yang dipimpinnya } \\
\text { ('Each person is a leader and each }\end{array}$ & $\begin{array}{l}\text { responsible for what they } \\
\text { person is responsible to what is led lead. } \\
\end{array}$ & \\
& by her or him') & \\
\hline
\end{tabular}

Regarding this type of modulation, there is only one case identified. It is shown in table $2 b .4$ that the clause "Apa yangdipimpinnya" ('what is led by him or her') as a part of the equivalent for Kullukum ra'in wa kullukum masullun a raiyat ('Each person is a leader and each person is responsible to what is led by her or him') is given in passive voice. This passive noun clause functioning as an object in the Indonesian source text indicated by the existence of prefix $\{$ di\}in the verb Pimpin ('lead') is translated into an active noun clause with the same function as an object in the English target text, 'what they lead'. It is, therefore, there is a change of point of view from passive to active. Although there is a change in the point of view, the readers of the target text and the source text get the same comprehension as the message in the source language text is the same with the message in the target text.

Table 2c: Oblique Translation Strategy; Equivalence

\begin{tabular}{|c|c|c|c|}
\hline No. & Arabic Language & Indonesian Language Text & English Language Text \\
\hline 1 & Ma'assalamah & $\begin{array}{l}\text { "Ma'assalamah70 } \\
70 \text { Selamat jalan }\end{array}$ & $\begin{array}{l}\text { Ma'assalamah24 } \\
\text { 24 Farewell }\end{array}$ \\
\hline 2 & Ma’annajah. & Ma'annajah. Good luck. & Ma'annajah. Good luck. \\
\hline 3 & $\begin{array}{l}\text { Qila wa Qala } \\
\text { ('No idea whether it is true } \\
\text { or not') }\end{array}$ & $\begin{array}{l}\text { Qila wa qala30, orang Minang masih } \\
\text { anak cucu dari Alexander Agung. } \\
\text { ('No idea whether it is true or not, } \\
\text { Minang people are the descendants of } \\
\text { Alexander the Great.') } \\
30 \text { Adalah ungkapan Arab yang dipakai } \\
\text { untuk mengawali sesuatu yang belum } \\
\text { jelas, rumor, legenda, } \\
\text { dsb. } \\
\text { ('It is Arabic expression which is used } \\
\text { to initiate something which is not clear } \\
\text { whether it is true or not, whether it is a } \\
\text { rumour, legend, etc.') }\end{array}$ & $\begin{array}{l}\text { Purportedly, Minang people } \\
\text { are the descendants of } \\
\text { Alexander the Great. }\end{array}$ \\
\hline
\end{tabular}

The information is given through the Arabic expressions in data (1) to (3) in table 2c are cultural; it shows the way to express a prayer for the goodness of others when parting, “ma'assalamah" (May you arrive safely to your destination'), (1) a prayer when supporting others in facing a situation like an exam, "ma'annajah" ('good luck'), (2) and it is an idiomatic expression when dealing with the situation which is considered not clear yet or speculation, "qila wa Qala" ('No idea whether it is true or not') (3). The detail meaning contained in each of Arabic expressions may not be similar in the equivalents, like in data (1), the Arabic expression “ma'assalamah" ('May you arrive safely to your destination') is used to pass a prayer for the safety of others when parting (that others be safe, that others have goodness on their ways until reaching their destination). In the source text, the equivalent which is given is exactly like the way the Indonesian say when they send others to a long trip 'Selamat Jalan' so it is not in every parting while "ma'assalamah" is usually used in every parting, short trip, and long trip. In the target text, the expression 'farewell' which contains the meaning of saying goodbye to each other, a good parting is used as its equivalent; there is no a message of praying given to those who are leaving. It is not in their culture so the equivalent "farewell" can be considered as appropriate.

In data (2), the Arabic expression Ma'annajah is used to pray for others that whatever they are about to do blessed by Allah and ending in a good way. There is no Indonesian equivalent mentioned in the source text; the author just uses the English expression 'good luck' as the situation described in the story required the use of two languages only (Arabic and English). While in the data (3), the Arabic expression Qila waQala is a proverb used to express a situation where the truth has not been confirmed yet. The English equivalent 'purportedly' can be taken as a representative message.

\section{Additional Translation Procedures under Oblique Translation Strategy}

The data in this subchapter deal with oblique translation strategy also. They are put under different subchapter to emphasize that the following three procedures (amplification, economy, and explicitation) are considered as new procedures which are called supplement translation procedures. They were not there in the oblique translation strategy 
before; they are needed to fulfil the need for the recent researches in cases of addition (amplification and explicitation) and cases of reduction or omission (economy).

Table 3a: Oblique Translation Strategy; Amplification

\begin{tabular}{|c|c|c|c|}
\hline No. & Arabic Language & Indonesian Language Text & English Language Text \\
\hline 1 & Allahu Akbar & "Allahu Akbar!" & "Allahu Akbar! God is great!" \\
\hline 2 & Alhamdulillah & $\begin{array}{l}\text { Tiba-tiba Said mengangkat tangan } \\
\text { dengan gembira menggumamkan } \\
\text { Alhamdulillah dan berteriak yes. }\end{array}$ & $\begin{array}{l}\text { Suddenly Said's hand shot up } \\
\text { happily, he whispered } \\
\text { Alhamdulillah, thank God and } \\
\text { yelled yes! }\end{array}$ \\
\hline 3 & tawaduk. & $\begin{array}{l}\text { Pergunakanlah dengan baik dan } \\
\text { tawaduk. }\end{array}$ & $\begin{array}{l}\text { Use it well and tawaduk, full of } \\
\text { responsibility. }\end{array}$ \\
\hline 4 & Rasulallah. & selama beliau menjadi Rasulallah. & $\begin{array}{l}\text { in his time as the Messenger of } \\
\text { Allah. }\end{array}$ \\
\hline 5 & $\begin{array}{l}\text { Laa takhaf ya akhi } \\
\text { ('Don't be afraid, brother') }\end{array}$ & $\begin{array}{l}\text { Laa takhaf ya akhi!. Jangan takut. } \\
\text { ('Don't be afraid.') }\end{array}$ & $\begin{array}{l}\text { Laa takhaf ya akhi!. Don't be } \\
\text { scared, brother }\end{array}$ \\
\hline
\end{tabular}

All data are shown in table 3a deal with additional information done in the target text. This information is not stated in the source text. It is assumed that the author does not consider the Arabic expressions used in the source text as no longer borrowing. The Arabic expressions in data (1) Allahu Akbar, (2) Alhamdulillah, (3) tawaduk ('with full of responsibility'), and (4) Rasulullah are common terms used in the daily life of Moslem communities. They deal directly with Islam religion so most of the readers of the source Indonesian text will know and understand these Arabic expressions; equivalents to these Arabic expressions are not needed in the source text. However, it is not the same when dealing with the readers of the English target text. The translator needs to explain the meaning of those expressions so the amplification procedure is applied.

The information (1) God is great, (2) thank God, (3) full of responsibility, and (4) Messenger of Allah added following the Arabic expressions show the equivalent of each.

This procedure under the oblique translation strategy strengthens the understanding of the target readers regarding the Arabic borrowing words or sentences. Unlike data in (5), it shows a different case where the translator adds the information to the equivalent in the target text which is not given in the source text; the equivalent of the Arabic expression "ya akhi" is not mentioned in the source text because it has been used before in other parts of the novel (Hermawan \&Tanjung, 2018; Shabani, Emadi \& Daftari, 2019). By applying this procedure of Translation, amplification, the translator manages to keep the close relationship among students shown in the Islamic boarding school mentioned in the source text.

Table 3b: Oblique Translation Strategy; Economy

\begin{tabular}{|c|c|c|c|}
\hline No. & Arabic Language & Indonesian Language Text & English Language Text \\
\hline 1 & Shabahal khair, ya akhi & $\begin{array}{l}\text { "Shabahal khair14, ya akhi15 Burhan. } \\
14 \text { Selamat Pagi (Arab) } \\
15 \text { Akhi artinya saudaraku, sebutan } \\
\text { yang umum dipakai untuk menyebut } \\
\text { seseorang di PM }\end{array}$ & $\begin{array}{l}\text { "Shabahal khair, good } \\
\text { morning, Burhan }\end{array}$ \\
\hline 2 & "Qum ya akhi, Tahajjud, & $\begin{array}{l}\text { "Qum ya akhi, Tahajjud, " bisik Kak } \\
\text { Is membangunkan aku malam buta, } \\
\text { seperti permintaanku. }\end{array}$ & $\begin{array}{l}\text { "Time for night prayer, } \\
\text { whispered Kak Is, waking me } \\
\text { up in the dead of the night, as } \\
\text { I'd requested. }\end{array}$ \\
\hline 3 & Qiyaman ya akhi & $\begin{array}{l}\text { Qiyaman ya akhi 51!" } \\
51 \text { Bangun saudaraku. }\end{array}$ & Qiyaman. Wake up!” \\
\hline 4 & $\begin{array}{l}\text { yarmi kurah ila wasat, ilal } \\
\text { yusra, wa gooool } \\
\text { ('The ball was thrown to } \\
\text { the middle, then was } \\
\text { kicked to the left, and } \\
\text { goal!') }\end{array}$ & $\begin{array}{l}\text { "...yarmi kurah ila wasat, ilal yusra, } \\
\text { wa gooool } 41 \text { !" teriak Amir sang } \\
\text { komentator heboh. } \\
\text { (...'the ball was thrown to the middle, } \\
\text { then was kicked to the left, and goal!' } \\
\text { shouted Amir the commentator) } \\
41 \text { Bola dilempar ke tengah, lalu } \\
\text { ditendang ke kiri, dan gool. } \\
\text { ('The ball was thrown to the middle, } \\
\text { then was kicked to the left, and goal!') }\end{array}$ & $\begin{array}{l}\text { “...goal!".. . shouted Amir the } \\
\text { commentator. }\end{array}$ \\
\hline
\end{tabular}


Table 3b: Economy shows there is an act of omitting information which is given in the source text. The three data $(1-3)$ regarding this oblique translation strategy are located in daily conversation in the form of sentences while data (4) is a part of a report given in a football match. The Arabic expression "ya akhi"(o, brother') in data (1) is introduced to the rest of the source text by providing its equivalent saudaraku ('my brother') as footnotes. It is a way to call someone in the Islamic boarding school to build a close friendship among the students there that they are all brothers. When it is omitted from the target text like in data (1) to (3), the close relationship built in the Islamic boarding school cannot be seen by the readers of the target text. The Arabic expression "qum" ('wake up') which means 'wake up' in data (2) is also omitted in the target text. This can be accepted as the context following the expression indicates the act of waking someone up, so the message received by the readers in the target text will still be the same as in the source text. While the omission of the expression " $\boldsymbol{y a}$ akhi" ('o brother') occurs in data (3) changes the closeness between the speaker and the hearer; it becomes a strong command "wake up!" The economy procedure used in data (4) is no longer dealing with the call "ya akhi" (o, brother'); it deals with pieces information given in an oral comment reported in a football match on the spot. The equivalent is provided in the source text as footnotes but the translator chooses not to use it in the target text. She omits most of the comments except the last word stating in a lengthy way "goooool" that one of the football players managed to make a score. By this procedure, the readers of the target text will not be able to see the process in the match before a score is made.

Table 3c: Oblique Translation Strategy; Explicitation

\begin{tabular}{|c|c|c|c|}
\hline No. & Arabic Language & Indonesian Language Text & English Language Text \\
\hline No. & Arabic Language & Indonesian Source Text & English Target Text \\
\hline 1 & $\begin{array}{l}\text { Uthlubul ilma walau } \\
\text { bisshin }\end{array}$ & $\begin{array}{l}\text { Uthlubul ilma walau bisshin } \\
\text { 'Tuntutlah ilmu bahkan walau ke } \\
\text { negeri sejauh China.' } \\
\text { "Ke China saja disuruh, apalagi hanya } \\
\text { sekedar ke Jawa Timur" }\end{array}$ & $\begin{array}{l}\text { Seek knowledge, even if it's as } \\
\text { far as China. } \\
\text { "An Arabic proverb even tells } \\
\text { us to go to China, and I'm only } \\
\text { going to East Java" }\end{array}$ \\
\hline 2 & $\begin{array}{l}\text { Syawal. } \\
\text { ('Syawal is the name of a } \\
\text { month of the Islamic } \\
\text { calendar') }\end{array}$ & $\begin{array}{l}\text { Kami baru kembali masuk sekolah } \\
\text { pertengahan bulan Syawal. } \\
\text { (We will come back to school again in } \\
\text { the middle of Syawal month') }\end{array}$ & $\begin{array}{l}\text { We'd come back to school } \\
\text { again in the middle of the } \\
\text { Shawwal month of the Islamic } \\
\text { calendar }\end{array}$ \\
\hline
\end{tabular}

Table 3c shows 2 cases of oblique translation strategy namely explicitation. The additional information "An Arabic proverb" in data (1) and "month of the Islamic calendar in data (2) change the implicit message of the Arabic expressions explicit. When the Arabic expression Uthlubul ilma walau bisshin ('Seek knowledge, even if it's as far as China') is given its equivalent in the Indonesian source text, there is no explicit information indicating that the expression is a proverb even in the next sentence following the equivalent. However, the translator who makes her mind not to take the Arabic expression into the target text makes the equivalent in the target text not clear. As she is aware that the Arabic expression is a proverb, she adds the information in the second sentence following the equivalent with explicit information "an Arabic proverb" as a subject. Now the information contained in the equivalent of the Arabic expression Uthlubul ilma walau bisshin ('Seek knowledge, even if it's as far as China') becomes clear that it is an Arabic proverb.

The case is different from the Arabic word "syawwal" ("the name of a month in the Islamic calendar) in data (2) regarding the name of a month. The author gives no equivalent in the source text as it is assumed that any equivalent will no longer be needed for the readership of the source text; they all know this information and they are familiar with this Arabic word (Erlina, 2016; Mahmud, 2018). However, the translator realizes that the readership of the target language may not know about this so she adds more information "month of the Islamic calendar" to her Translation. By doing this, the translator changes the implicit information about Syawal month into explicit that it is the name of the month in the Islamic calendar.

\section{CONCLUSION}

Regarding the objectives of the research, it can be achieved from all the discussion that

1. The linguistic units of Arabic expressions occurred in the novel Negeri 5 Menara ('The Land of Five Towers') cover all units from sentence to word and the themes brought along in the Arabic expression can be identified as follows;

a) Sentences or clauses are used to express prayers, a part of a verse in Al-Quran, proverbs, wise words, and daily conversation;

b) Phrases are used to express the names of subjects at school, titles;

c) Words are used for specific terms like school rules.

2. The strategies used in the Translation are

a) Direct Translation with only two procedures; borrowing and literal Translation and; 
b) Oblique Translation with all procedures; transposition, modulation (Abstract for Concrete, The Part for the Whole, One Part for Another, and Active to Passive), equivalence, adaptation and there are,

c) Other three additional procedures also located; amplification, economy, and explicitation;

3. Not all procedures are used individually; some are used together as a combination, the combination of borrowing and literal Translation under the same translation strategy (direct translation strategy), the combination of borrowing and economy under mixed strategies (direct translation strategy and oblique translation strategy).

\section{LIMITATION AND STUDY FORWARD}

The whole work of this research which is then translated into English as the target text opens another gap on how the Arabic expressions are translated, which are so far only shown in their equivalents. All the data in this research allow carrying out more research. What changes found and what kinds of shifts occurred in the data can be some possible objectives to be discussed thoroughly in the next study collaborating with researchers who have Arabic competence.

\section{ACKNOWLEDGEMENT}

The authors reaffirm that there's no conflict of interest. Thanks to the Faculty of Sciences Universitas Padjadjaran, Indonesia for its support and for providing us the opportunity to enhance our knowledge by conducting this valuable research work.

\section{AUTHORS CONTRIBUTION}

Erlina Zulkifli Mahmud has developed the concept of the paper and contributed to developing up to a good journal publication. On the other Bima Bayusena and Ratna Erika Mawarrani have also contributed to writing the methodology, results and bring conclusion.

\section{REFERENCES}

1. Afrouz, M. (2019). How Different Muslim Translators Render the Holy Qur' an into English ? The Case Study of Sunni, Shia and " neither Sunni nor Shia. SKASE Journal of Translation and Interpretation, 12(1), 02-14.

2. Al-khresheh, M., \& Almaaytah, S. (2018). English Proverbs into Arabic through Machine Translation. International Journal of Applied Linguistics \& English Literature, 7 (5), 159 - 166. https://doi.org/10.7575/aiac.ijalel.v.7n.5p.158

3. Al-khresheh, M., Khaerurrozikin, A.,\& Zaid, A. (2020). The efficiency of using pictures in teaching speaking skills of non-native Arabic beginner students. Universal Journal of Educational Research, 8 (3). https://doi.org/10.13189/ujer.2020.080318

4. Al-khresheh, M. (2016A). A review study of contrastive analysis theory.Journal of Advances in Humanities and Social Sciences, 2 (6), 330-338. https://doi.org/10.20474/jahss-2.6.5

5. Al-khresheh, M. (2016B). A review study of error analysis theory. International Journal of Humanities and Social Science Research, 2, 49-59. https://doi.org/10.20474/jahss-2.6.5

6. Al-khresheh, M. (2015). A review study of interlanguage theory. International Journal of Applied Linguistics \& English Literature, 4 (3), 124 - 131. https://doi.org/10.7575/aiac.ijalel.v.4n.3p.123

7. Ahmad, Fuadi. (2017). Lampung: Fakultas Tarbiyah dan Keguruan. IAIN Raden Intan.

8. Alawiyah, N. L., Royani, A., Nawawi, M., Islam, U., Syarif, N., \& Jakarta, H. (2016). Program Studi. Pendidikan Bahasa Arab, 3(2), 217-230. https://doi.org/10.15408/a.v3i2.4642

9. Erlina. (2016). Translation Studies: Basic Guidelines for Students of Translation Major. Bandung: Sastra Unpad Press, CV Semiotika.

10. Fitriani, N. C. (2014). A Translation Analysis of Address Terms of Negeri 5 Menara In The Land of Five Towers.

11. Folklores. Written in Three Languages, 280(Basa), 417-429.

12. Fuadi, A. (2016a). Negeri 5 Menara. (M. Yulistianti, Ed.) (25th ed.). Jakarta: Gramedia Pustaka Utama.

13. Fuadi, A. (2016b). The Land Of Five Towers: A Novel By A Fuadi. (D. "Yayi" Dewanti, Ed.) (3rd Ed.). Jakarta: Gramedia Pustaka Utama.

14. Gatpandan, M. P., \& Ambat, S. C. (2017). Implementing knowledge discovery in enhancing university student services portfolio management in higher education institutions, Journal of Advanced Research in Social Sciences and Humanities, 2(4), 211-220. https://doi.org/10.26500/JARSSH-02-2017-0306

15. Hermawan, H., \& Tanjung, S. (2018). A Bahasa Indonesia-English translation analysis of Negeri Lima. Menara and The Land of Five Towers, 5(1), 19-31. https://doi.org/10.21831/lt.v5i1.8065

16. Heshmatifar, Z., \& Biria, R. (2015). Exploring the Translation Strategies Utilized for the Rendition. economic terms from English into Persian, 2(8), 111-127.

17. Jean-Paul Vinay, \& Darbelnet, J. (1995). Comparative Stylistics of French and English: A Methodology for Translation. Amsterdam/Philadelphia: John Benjamins. https://doi.org/10.1075/btl.11

18. Mahmud, E. Z. (2018). Strategies in Translating Minangkabau Cultural Words in The Land of Five Towers ‘ Negeri Lima Menara ', Fuadi 's Novel, 166(Prasasti), 476-482. https://doi.org/10.2991/prasasti-18.2018.87

19. Mahmud, E. Z., Ampera, T., \& Sidiq, I. I. (2018). Documenting Sundanese Literature by the Presentation of It 
20. Mahmud, E. Z., Bayusena, B., \& Mawarrani, R. E. (2018). Translation Equivalences of Islamic Terms in the Novel. The Land of Five Towers ' Negeri Lima Menara, 4(2), 31-39. https://doi.org/10.11648/j.ijalt.20180402.12

21. Molina, L., \& Hurtado, A. A. (2002). Translation Techniques Revisited: A Dynamic and Functionalist Approach, Meta. Journal Des Traducteurs, 47( 4), 498. https://doi.org/10.7202/008033ar

22. Muyasyaroh, A. (2017). Nilai-nilai Pendidikan Akhlak Yang Terkandung Dalam Novel Negeri 5 Menara Karya

23. Newmark (1988). A Textbook of Translation (1 st ed.). Prentice Hall International (UK) Ltd, 1988

24. Owji, Z. (2013). Translation Strategies: A Review and Comparison of Theories. Translation Journal, 17(1).

25. Perdana, H. D. (2017). Strategi Penerjemahan. Bahasa Arab, 9(1), $143-160$. https://doi.org/10.21274/1s.2017.9.1.143-160

26. Reza, M., \& Qadimi, F. (2016). Study of Translation Strategy Applications in Clothing Brand Advertising Slogans in Iran Study of Translation Strategy Applications in Clothing Brand Advertising Slogans in Iran, (June).

27. Safitri, L. (2015). Nilai-Nilai Pendidikan Islam Dalam Novel Trilogi Negeri 5 Menara Karya Ahmad Fuadi.

28. Shabani, E. A., Emadi, N., \& Daftari, F. (2019). Examining the Translations of Forough Farrokhzad's Selected Poems by a Native and a Non-Native Speaker Using Vinay and Darbelnet' s Model Assistant Professor of Applied Linguistics, Department of Foreign Languages. International MA in Translation Studies, English Department, University of Tehran, Iran, 9(1), 77-91.

29. Sharei, V. (2017). A Comparative Study of the Strategies Employed in quot; The Old Man and the Sea quot. Translated from English into Persian based on Vinay and Darbelnet 's Model, 7(4), 281-286. https://doi.org/10.17507/tpls.0704.06

30. Suryawinata, Z., \& Hariyanto, S. (2016). Translation: Bahasan Teori \&amp; Penuntun Praktis Menerjemahkan (Revision). Malang: MNC Media Nusa Creative.

31. Sutarno, S. L., \& Ibrahim-Bell. (2000). Translation Procedures used in Translating Maitreya Buddhist Text , 素根与深耕. Mandarin into Indonesian, 129-134.

32. Umamaheshwari, J. (2016). Techniques and Method's of Translation, 40-42.

33. Vinay, J. P., \& Darbelnet, J. (1995). Comparative Stylistics of French and English: A Methodology for Translation. Amsterdam/Philadelphia: John Benjamins, 1995. https://doi.org/10.1075/btl.11 